\title{
Ownership Concentration and Environmental Information Disclosures
}

\author{
Tangmei Yuan \\ Department of Accounting \\ Linyi University \\ Shandong, China
}

\author{
Guirong Wang \\ Women \& Children's Health Care Hospital of Linyi \\ Shandong, China
}

\begin{abstract}
In order to investigate the ownership concentration of influence environmental information disclosure and market reactions, this paper use Chinese all Ashare listed companies of main board market in 2012 as samples, and the research conclusion indicate that: (1) The higher tradable shares, and the higher the institutional investor shareholding of listed companies will be more and better disclosure of environmental information. (2) The controlling shareholder concentration suppresses the disclosure of the environmental information in the listed company. The particularity of not all of China's stock are in circulation, which is the reason why the former scholars cannot find out the significant influence of the shareholding structure on China's environmental information disclosure. (3) The first major shareholder has no significant impact on environmental information disclosure. In short, institutional investors and equity circulation are conducive to environmental information disclosure, while control concentration is the opposite. (4) The listed companies environmental information disclosure behavior index and disclosure quality index are all significantly positive with the company's next seasonal added value. In short, the capital market responses strongly to the environmental information disclosure.
\end{abstract}

Keywords-environmental information disclosure; institutional investors; ownership concentration; tradable share; added value

\section{INTRODUCTION}

Enterprise is the direct creator of social wealth, also is main producers of the environment pollution, therefore, environmental pollution governance requires enterprises actively participate in. Enterprise full disclosure of environmental information, it is the precondition of environmental governance, is also the important way that investors understand company and important reference for investment decisions. Accounting information usually have certain information content and value for investors, and different types of information disclosure has a different influence on stock prices and stock trading volume (Wang Yuetang etc., 2001). At the same time, the quality and level of the environmental information disclosure can reflect the corporate implementation of social responsibility. So, strengthen the environmental information disclosure research has important theoretical and practical significance. This article with all of the 2012 a-share listed companies as research samples, in-depth analysis of the influence ownership concentration of corporate environmental information disclosure and market reaction, the targeted facilitate is to promote the continuous improvement of enterprise environmental information disclosure.

\section{LITERATURE REVIEW}

Foreign research on environmental information disclosure originated the social responsibility information disclosure in the 1940s, become a research hotspot after 70s. In the cause of the environmental information disclosure, previous scholars divided it into two aspects to study: companies choose active disclosure of environmental information disclosure and the interference factors. The causes of companies choose to take initiative and proactivity to disclose environmental information are to avoid political cost, prevent reputational damage and fulfill social responsibility, etc. Maltby (2004) research shows that: the enterprise can show their special and important value through the environmental information disclosure. So enterprises actively improve its value to society not only response to the demand of the society.

Interference factors of corporate disclosure of environmental information mainly includes the industry sensitivity (Comier et al, 2005; Frost, 2007), external control (Porteiro, 2008), company size, financial condition, debt levels, and corporate governance mechanism. (1) The existing study consensus that industry factors affect the enterprise's environmental information disclosure (Cormier \& Gordon, 2001). Halme \& Huse (1997) studied the European countries, such as Sweden, Spain, Finland, Norway, and environmental information disclosure situation, found that the industry category is a significant influence factor on environmental disclosure. (2) Dierkes \& Coppock (1978); Eng \& Mak (2003); Clarkson et al (2008) research found that there are positive relationship between enterprise scale and the level of environmental information disclosure. (3) The existing research does not have a unified relationship between the company's financial position, debt level and environmental information disclosure. Cormier \& Gordon (2001), Ahmad et al (2003), Maria \& Jay (2006) found that companies performance level was positively related to the environment information disclosure. However, Freedman \& Jaggi (1982), Ingram \& Frazier (1980), research drawn the 
opposite conclusion. Ferguson (2002), Clarkson et al. (2008) suggests that there are positive correlation between the debt level and environmental information disclosure, and Jens en, Meek, and Gray research conclusion is on the contrary. (4) Halme \& Huse (1997) found that ownership structure has a significant influence on environmental disclosure. Comier et al (2005) found that the stock risk, equity structure affects the quality of environmental information disclosure. Brammer \& Pavelin (2006) suggests that equity concentration is negatively related to the quality of environmental information disclosure. El-Gazzar (2003) found that institutional investors were positively correlated with environmental accounting information disclosure level.

Chinese research have showed that industry factors, external pressure, the company size has a significant influence on environmental information disclosure; the company's debt level has little influence on environmental information disclosure. And corporate performance although has impact on environmental information disclosure, but have not a unified direction; Chinese research result is on the contrary to the overseas research conclusion for ownership structure influence environmental information disclosure. the research result is not sure for stock market performance, business performance, joining together of two position of chairman and general manager influence on environmental information disclosure; Research of capital markets reaction for the environmental information disclosure also is not sufficient, there is still no exact significant conclusions. Thus in this paper, we will to do further research on market factors of influence environmental information disclosure and market reactions.

\section{THEORY ANALYSIS}

The theory, used to interpret environmental information disclosure motivation and market reaction, are mainly fiduciary duty theory, external pressure theory, voluntary disclosure and signaling hypothesis, and modern behavior finance theory, etc.

\section{A. The Fiduciary Duty Theory}

American scholar, John maresca regard that the enterprise is used to create wealth, but companies should be responsible during create wealth process, to ensure that the entire process would be to benefit the whole society, Companies are not only responsible for its owners and shareholders, also deal with more responsible for the public, the international community and the world. At present, the theoretical perspectives is relatively popular in the accounting theory field, Such as Brenton Fielder and Glen Lehman say that, in the Accounting, Fiduciary duty, and environment factors, environmental information should be open, so that other people can access to these information, and to evaluate it. The company, as one member of social, has a responsibility to consider environmental factors in the long-term investment decisions. It also has responsibility to provide the environmental information to other members of society.

\section{B. External Pressure Theory}

External pressure theory argues that enterprise environmental information disclosure is due to the pressure from outside. Enterprises external pressure in the aspect of environmental information disclosure can be divided into two aspects: one pressure is come from the government; the second pressure is come from social public. Generally speaking, the former is achieved by the form of a series of laws and regulations promulgated; it is a kind of direct pressure. Companies hope that public thinks its activities are legal through the activities of the environmental information disclosure, and to relieve the enterprise social pressure (Patten, 2000); while the latter would be implemented by public opinion or market behavior, it is a kind of indirect pressure. Under the theory of social public pressure, if enterprise mainly interested party lose confidence in corporate performance, they can take back their legitimacy power, such as customers stop buying the product, shareholders sell stocks, government stop subsidies or fines, and environmentalists make complaint against, etc.

\section{The Voluntary Disclosure and the Signaling Hypothesis}

Voluntary disclosure theory regards that, although external pressure theory has certain reasonable and persuasive, it does not explain enterprise voluntary disclosure of environmental information. This view think that inadequate disclosure of corporate information can discount enterprise investment value for the information users. Even list it in the worst, it would do more harm to the enterprise financing and the future development. Signal transmission is used to solve a series of problems caused by information asymmetry problem, Such as adverse selection problem. When information is not timely disclosed, investors tend to think of it as a bad news. In order to avoid the occurrence of adverse selection problem, companies with "good news" more willing to take the initiative to disclose information, separate himself apart from the "bad news" enterprise (Dye, 1985; Verrecchia, 1983). Maltby (2004) research shows that the enterprise can show its special and important value through the social environment information disclosure. So enterprise is not only in social pressure to disclosure information, in order to show it's not the worst, at the same time, in order to avoid the information user make a bad guess in the case of lack information, willing to take the initiative to open more information. In addition, the holding company's managers have incentive to signal transfer undervalue through voluntary disclosure, make their stock is worth more (Healy \& palequ, 2001).

\section{The Modern Behavioral Finance Theory}

The modern behavioral finance theory, basis on the effective financial market theory, using cognitive psychology analysis investor behavior, is an important theory to effectively explain the investor behavior. The theory regards human economic behavior under the influence of psychological factors, such as confidence, remorse, experiences, feelings, attitudes, opinions, attention and expectation, etc, and changing people's expectations and market decision-making behavior, which can be used to 
explain the investors' market reaction for information disclosure. Chun Wang and Xu Longbing (2009), the Long Yuee (2010) argues that investor confidence, as investors' specific psychological phenomenon, will affect the company stock trading price and trading volume through the investor beliefs and behavior change, and thus affect the value of the company.

\section{RESEARCH HYPOTHESIS PUT FORWARD}

Based on the above theory and previous research, this paper put forward research hypothesis from the following several aspects respectively, to further examine environmental information disclosure influencing factors and the market reaction.

\section{A. Concentration of the Largest Shareholder}

"Sole majority shareholder" is the unique characteristic of China's listed companies. The higher the shareholding ratio of the largest shareholder, the more concentrated ownership is in the hands of the largest shareholder, listed companies are easily manipulated by the largest shareholder. Generally speaking, the higher the ownership concentration is, the lower the level of information disclosure is. At present, China's environmental accounting information disclosure is still in the stage of integration of voluntary disclosure and compulsory disclosure. In order to examine the relationship between the degree of environmental information disclosure and the distribution of ownership structure, the first major shareholder shareholding ratio of listed companies is introduced as an indicator of the total ownership concentration of listed companies. Therefore, the following hypothesis is proposed:

H1: The largest shareholder shareholding is negatively correlated with the disclosure of environmental information.

\section{B. Concentration of Controlling Shareholders}

The control of a listed company is often not in the hands of the largest shareholder, in particular, complex enterprise groups may still have a firm control over the enterprise through the pyramid structure, and in the case of that there are not a lot of direct holdings of listed companies. Shleifer and Vishny (1997) believed that large investors may represent their own interests, without to cooperate with other investors in the interests of the company.

Deep-seated controllers are rarely subject to stock market discipline and minority shareholder protection policies, and have greater discretion to pursue their own interests rather than corporate (Claessens et al. 2002). Therefore, controlling shareholders' high equity concentration means that the controlling shareholders have enough voting rights to manipulate the chairman, directors and managers, that reducing the degree of environmental information disclosure. Generally, the higher the shareholding ratio of the controlling shareholder is, the lower the level of information disclosure is. Therefore, the introduction of the shareholding ratio of the controlling shareholders of listed companies serves as another indicator of the concentration degree of "total equity". Haskins atl (2000) research also shows that the equity of European and American companies is dispersed, and the large number of shareholders has high requirements on information disclosure, and the company's voluntary disclosure is higher. Asian companies are relatively concentrated, unlike western shareholders, who are less demanding and less willing to disclose their reports. The following hypotheses are proposed:

$\mathrm{H} 2$ : The shareholding ratio of controlling shareholders is negatively correlated with the level of environmental information disclosure.

\section{The Proportion of Tradable Share}

According to the external pressure theory, the social public achieves the pressure on the company by public opinion or market behavior. When a company created value does not agree with the value of social identity, the legitimacy of companies suffered threat from actual or potential. When tradable share, lose confidence in corporate performance, as the main stakeholders of listed companies, tradable shares can bring a lot of pressure to the financing of listed companies through undersell company's shares or sales resistance. The higher tradable share proportion of listed companies, the higher pressure put on listed companies to disclose more environmental information. Therefore put forward:

H3: The proportion of tradable share is positively related to the environment information disclosure.

\section{Concentration of the Institutional Investors}

El-Gazzar (2003) empirical study found that institutional investors holding were positively related to the environment accounting information disclosure. While Huang Jun and chun-na zhou (2012), research results show that the institutional investors holding have not related with environmental information disclosure level. In fact, institutional investors have incentive to actively monitor the company management (Pound, 1988; Shleifer \& Vishney, 1986). Maug (1998) believe that the lack of marketability makes institutional investors turn into long-term investors, and then forcing them to pay close attention to the enterprise long-term profitability rather than short-term gains, to monitor the company's management in order to increase the company value(Saunders et al., 2006; Mitra, 2002; Chung et al., 2002). Because of compared with other natural persons, institutional investors is a large investors, have more experienced and have a plenty of resources, as well as have more relevant professional knowledge to monitor the company management. Seek to maximize yield as the desire of the institutional investors, also give enterprise managers greater external pressure. As rational investors, institutional investors in China should be able to effectively to promote corporate disclosing environmental information. Therefore put forward:

H4: Concentration of the institutional investors is positively related to the environment information disclosure. 


\section{E. The Market Reaction of Environmental Information Disclosure}

In today's increasingly prominent environmental problem in China, investors and other stakeholders have started to pay close attention to the environmental protection, Environmental information disclosure quality and disclosure level can reflect the corporate implementation of social environment responsibility. According to the modern behavioral finance theory, the company's disclosure of environmental information must have certain information content for investors, changing people's expectations and market decision-making behavior, affect stock market price and trading volume, and thus affect the company value. Therefore put forward:

H5: Environmental information disclosures are positive related to the added market value of listed companies.

\section{VARIABle SElection, MEASUREMENT AND RESEARCH MODEL}

\section{A. Variable Selection and Measurement}

Environmental information disclosure index selection and measurement. In order to comprehensive and effective reflect environmental information disclosure and disclosure degree, this paper choose three index to measure environmental information disclosure of listed companies: Whether disclosure of environmental information (Disc), Disclosure quantity index of environmental information (EDI1), Disclosure quality index of environmental information (EDI2) .

(1)Whether disclosure of environmental information index-Disc (disclosure), is a dummy variable, Whether through the disclosure of environmental information to the assignment. Company disclosure of environmental information, assignment 1 , otherwise assigned a value of 0 .

(2)Disclosure quantity index of environmental information-EDI1, index assignment according to the number of entries of environmental information disclosure, each of entries of the enterprise environment information disclosure has 0.01 points, a summary score as environmental information disclosure quantity index. In
2012, the enterprise environmental information disclosure items only one company more than 100 entries, so the limited environmental accounting information disclosure index is the highest score of 1 .

Quantity index's calculation formula is:

$\mathrm{EDI}_{1}=$ The actual number disclosure items $\times 0.01$

(3) Disclosure quality index of environmental information-EDI2. Environmental information disclosure index calculated by means of weighted average. Based on the experience of the predecessors, using content analysis, each entries of enterprise environment information disclosure can be divided into quantitative and qualitative description, assuming the qualitative and quantitative information have the same effect for investors. Each index adopt 0, 0.01, 0.02 as grading standards: If company has not disclosed any one entries of environment information, it's score is 0 ; If the entry has only disclosed qualitative information not quantitative information, it's score is 0.01 ; If the entry has both disclosed qualitative information and quantitative information, it`s score is 0.02 . Sum up each entry scores of a company, get the company's environmental information disclosure quality level index score, it is the company's quality index of environmental information disclosure. In 2012, only three Chinese enterprises' environmental information disclosure score more than 1 score, Therefore limit the highest score is 1 minute, more than 1 minute, calculated according to 1 score. Quality index`s calculation formula is:

\section{$\mathrm{EDI}_{2}=\sum$ Qualitative disclosure item number $\times 0.01$}

$+\Sigma$ both qualitative and quantitative disclosure item number $\times 0.02$

\section{B. Control Variable Selection and Measurement}

The choice of control variables. Research of scholars both at home and abroad agree that the company size, debt levels and types of listed companies will affect the enterprise's environmental information disclosure, In this study, we control them when verify the environmental information disclosure motivation and other influence factors. All the index and the index connotation explanation used in this paper listed in "Table I".

TABLE I. VARIABLES AND VARIABLE DEFINITION

\begin{tabular}{|c|c|c|}
\hline variables & & variables definition \\
\hline Disc & $=$ & $\begin{array}{l}\text { Disclosure environmental information assignment } 1 \text {, otherwise the value } 0 \text {. indicate companies } \\
\text { disclose environmental information or not. }\end{array}$ \\
\hline EDI1 & $=$ & $\begin{array}{l}\text { Sum up environmental information disclosure entry score, reaction company disclosure of } \\
\text { environmental information content quantity. }\end{array}$ \\
\hline EDI2 & $=$ & $\begin{array}{l}\text { weighting value of each entries content(adopt } 0 、 0.01 、 0.02 \text { standard for evaluation), reaction } \\
\text { company disclosure of environmental information content quality. }\end{array}$ \\
\hline$\triangle \mathrm{MVS}$ & $=$ & $\begin{array}{l}\text { The stock market value of listed company value compared with the } \\
\text { previous quarter in the hird quarter of 2013, standardized by total } \\
\text { assets. }\end{array}$ \\
\hline TradSh & $=$ & Proportion of tradable share \\
\hline INST & $=$ & Proportion of institutional investor share holding \\
\hline Top1 & $=$ & proportion of the largest shareholder share \\
\hline ContrSh & $=$ & the shareholding ratio of the controlling shareholder \\
\hline Size & $=$ & natural logarithm of total assets \\
\hline Lev & $=$ & Debt level \\
\hline
\end{tabular}


TABLE II. COUT

\begin{tabular}{llll}
\hline variables & & variables definition \\
$\mathrm{ID}$ & $=$ & industry dummy variable & \\
$\mathrm{t}$ & $=$ & 2012 \\
$\varepsilon$ & $=$ & error term & \\
\hline
\end{tabular}

\section{Research Model}

Reference to previous research model, and according to the increase of variables this study, designed the following regression model to verify the above hypothesis:

$\mathrm{EDI}_{\mathrm{it}}=\mathrm{a}_{0}+\mathrm{a}_{1} \mathrm{TopSH}_{\mathrm{it}}+\mathrm{a}_{2} \mathrm{CtrSH}_{\mathrm{it}}+\mathrm{a}_{3} \operatorname{TrdSH}_{\mathrm{it}}+\mathrm{a}_{4} \mathrm{INST}_{\mathrm{it}}+\mathrm{a}_{\mathrm{k}} \mathrm{Co}$ ntrols $_{\text {it }}+\Sigma \lambda_{\mathrm{j}} \mathrm{ID}_{\mathrm{j}}+\varepsilon($ Model 1)

$\Delta_{(\text {Model 2) }} \operatorname{MVS}_{\mathrm{it+1}}=\beta_{0}+\beta_{1} \mathrm{EDI}_{\mathrm{it}}+\beta_{2} \operatorname{Size}_{\mathrm{it}}+\beta_{3} \operatorname{Lev}_{\mathrm{it}}+\Sigma \gamma_{\mathrm{j}} \mathrm{IND}_{\mathrm{j}}+\varepsilon$;

Where, EDIit is the index of listed companies Environmental information disclosure, choose Disc; EDI1; EDI2 three variables to reflect respectively.

\section{THE SAMPLE DATA}

\section{A. Sample Selection Criteria and Data Sources}

This paper selects 2012 a-share listed companies in the Shanghai and Shenzhen stock exchange as the overall sample, then, deletes the not complete data companies and extreme value companies, the final samples is 2098 companies. This study of financial data and market value index derived from the CSMAR database, The environmental information disclosure data is obtained by Manual sorting according to the "corporate social responsibility report" in CSMAR database; Institutional investors holding data taken from Wind database.

\section{B. Descriptive Statistics}

"Table II" shows the descriptive statistics result of all samples. The mean of environmental information disclosure index are $0.190,0.016,0.030$ respectively in 2012 . Proportion of disclosure environmental information companies is only $19 \%$, and there are larger differences in environmental information disclosure level between differences enterprises. The mean of $\triangle \mathrm{MV} 3$ is 0.2937 in the third quarter of 2013, indicate that the stock market is active in the next quarter of environmental information disclosure in 2012.
TABLE III. All SAMPLES DesCRIPTIVE StATISTICS

\begin{tabular}{llllll}
\hline & minimum & maximum & mean & $\begin{array}{l}\text { standard } \\
\text { deviation }\end{array}$ & variance \\
\hline Disc & 0 & 1 & 0.190 & 0.395 & 0.156 \\
$\mathrm{EDI}_{1}$ & 0 & 1 & 0.016 & 0.056 & 0.003 \\
$\mathrm{EDI}_{2}$ & 0 & 1 & 0.030 & 0.100 & 0.01 \\
$\triangle \mathrm{MV} 3$ & -3.9149 & 16.2768 & 0.2937 & 0.6928 & 0.462 \\
$\mathrm{INST}$ & 0 & 0.981 & 0.272 & 0.265 & 0.07 \\
TrdSH & 0.038 & 1.000 & 0.741 & 0.287 & 0.082 \\
TopSH & 0.022 & 0.894 & 0.368 & 0.161 & 0.026 \\
CtrSH & 0.0000 & 0.8941 & 0.3693 & 0.1725 & \\
Size & 15.729 & 30.496 & 22.056 & 1.480 & 2.19 \\
LEV & 0.016 & 1.897 & 0.476 & 0.233 & 0.054 \\
\hline
\end{tabular}

\section{REGRESSION RESULTS AND ANALYSIS}

Model 1 regression results, $\mathrm{H} 2, \mathrm{H} 3, \mathrm{H} 4$ be verified.

For further analysis of the influencing factors of environmental information disclosure, regression the proposed model 1 and the results are shown in table 3 . It can be seen from the table 3: (1) the proportion of tradable shares, institutional investor shareholding ratio and environmental information disclosure of the three indexes have all positive correlation in $1 \%$ significant level.(2)The shareholding ratio of controlling shareholders is negatively correlated with the level of environmental information disclosure.(3) The largest shareholder shareholding has positive correlation with the disclosure of environmental information, But no significant. This suggests that the greater the proportion of tradable share the more disclosure of environmental information; Institutional investor shareholding concentration would encourage managers to disclose more environmental accounting information. The results agree with previous view that institutional investors plays supervision role in company, That is to say, institutional investors can affect enterprise environmental information disclosure. Therefore hypothesis $\mathrm{H} 2, \mathrm{H} 3, \mathrm{H} 4$ be validated.

Control variables: Company size have all positive correlation with three environmental accounting information disclosure level indexes at $1 \%$ significant level, This conclusion are consistent with previous research. Company debt level only has significant correlation with one of the environmental information disclosure index (Disc); it has not significant correlation with both quantity index and quality index. This does not agree with foreign mainstream view, but you can explain it using Jiang L.F.(2009) research conclusion. The top shareholder's holding has not significant correlation with three environmental information disclosure index. Indicate that top shareholder's concentration has not significant effect on the environmental information disclosure of listed companies. 
TABLE IV. THE REgRESSION RESULTS OF MODEL 1

\begin{tabular}{|c|c|c|c|c|c|c|}
\hline & B & Disc & B & $\begin{array}{l}\text { EDI1 } \\
t(n)\end{array}$ & $\mathbf{B}$ & $\begin{array}{c}\text { EDI2 } \\
t(n)\end{array}$ \\
\hline inter & -2.488 & $\begin{array}{l}-17.58 \\
(0.000)^{* * *}\end{array}$ & -0.276 & $\begin{array}{l}-12.92 \\
(0.000)^{* * *}\end{array}$ & -0.521 & $\begin{array}{l}-13.96 \\
(0.000)^{* * *}\end{array}$ \\
\hline TopSH & 0.006 & $\begin{array}{l}0.122 \\
(0.903)\end{array}$ & 0.009 & $\begin{array}{l}1.192 \\
(0.233)\end{array}$ & 0.016 & $\begin{array}{l}1.221 \\
(0.222)\end{array}$ \\
\hline $\mathrm{CtrSH}$ & -0.143 & $\begin{array}{l}-2.804 \\
(0.005)^{* * *}\end{array}$ & -0.013 & $\begin{array}{l}-1.75 \\
(0.080)^{*}\end{array}$ & -0.026 & $\begin{array}{l}-1.912 \\
(0.056)^{*}\end{array}$ \\
\hline TrdSH & 0.273 & $\begin{array}{l}3.376 \\
(0.001)^{* * *}\end{array}$ & 0.051 & $\begin{array}{l}4.158 \\
(0.000)^{* * *}\end{array}$ & 0.093 & $\begin{array}{l}4.342 \\
(0.000)^{* * *}\end{array}$ \\
\hline INST & 0.143 & $\begin{array}{l}4.348 \\
(0.000)^{* * *}\end{array}$ & 0.01 & $\begin{array}{l}2.062 \\
(0.039)^{* *}\end{array}$ & 0.02 & $\begin{array}{l}2.255 \\
(0.024)^{* *}\end{array}$ \\
\hline Size & 0.121 & $\begin{array}{l}18.109 \\
(0.000)^{* * *}\end{array}$ & 0.013 & $\begin{array}{l}12.924 \\
(0.000)^{* * *}\end{array}$ & 0.025 & $\begin{array}{l}13.938 \\
(0.000)^{* * *}\end{array}$ \\
\hline LEV & -0.116 & $\begin{array}{l}-3.06 \\
(0.002)^{* * *}\end{array}$ & -0.007 & $\begin{array}{l}-1.183 \\
(0.237)\end{array}$ & -0.01 & $\begin{array}{l}-1.046 \\
(0.296)\end{array}$ \\
\hline ID & Control & & Control & & Control & \\
\hline $\operatorname{Adj} R^{2}$ & 0.234 & & 0.149 & & 0.173 & \\
\hline $\mathrm{F}$ & $34.703(0.000)$ & & $20.35(0.000)$ & & 24.141( & \\
\hline Max VIF & 1.716 & & 1.716 & & 1.716 & \\
\hline
\end{tabular}

Note: 1) Model: $\quad \mathrm{EDI}_{\mathrm{it}}=\mathrm{a}_{0}+\mathrm{a}_{1} \mathrm{TopSH}_{\mathrm{it}}+\mathrm{a}_{2} \mathrm{CtrSH}$ ${ }_{i t}+a_{3} \operatorname{TrdSH}_{\mathrm{it}_{\mathrm{t}}}+\mathrm{a}_{4} \mathrm{INST}_{\mathrm{it}}+\mathrm{a}_{\mathrm{k}}$ Controls $\left._{\mathrm{it}}+\Sigma \lambda_{\mathrm{j}} \mathrm{ID}_{\mathrm{j}}+\varepsilon ; 2\right)^{* * *}, * *$ and $*$ is $1 \%, 5 \%$ and $10 \%$ significant level.

\section{A. Regression Results of Model 2 - H5 Be Verifie}

From "Table IV" can be seen: (1) The listed companies environmental information disclosure behavior index is significantly positive with the company's next seasonal added value at 5\% level. This suggests that the listed company disclosure of environmental information compared with the failure to disclose environmental information listed company, could improve the market value of listed companies. (2) The listed companies environmental information quantitative index and disclosure quality index are all significantly positive with the company's next seasonal added value at 5\% level. In short, the Capital market response strongly to the environmental information disclosure. This from another Angle shows that environmental information disclosure quality of listed companies can more greatly improve the listed companies market value in the period of stock market active. Consistent with our expectations, hypothesis 4 is verified.

TABLE V. REGRESSION RESULTS OF MODEL 2

\begin{tabular}{llllll}
\hline & \multicolumn{1}{c}{$\Delta \mathbf{M V 3}$} & & \multicolumn{1}{c}{$\Delta \mathbf{M V 3}$} & & \multicolumn{1}{c}{$\Delta \mathbf{M V 3}$} \\
\hline inter & $3.923^{* * *}$ & inter & $3.865^{* * *}$ & Inter & $3.895^{* * * *}$ \\
& -14.179 & & -14.491 & & -14.496 \\
Disc & $0.085^{* *}$ & $\mathrm{EDI}_{1}$ & $0.566^{* *}$ & $\mathrm{EDI}_{2}$ & $0.352^{* *}$ \\
& -2.092 & & -2.095 & & -2.284 \\
Size & $-0.15^{* * *}$ & Size & $-0.147^{* * *}$ & Size & $-0.148^{* * *}$ \\
& $9-11.693)$ & & $(-11.959)$ & & $(-11.982)$ \\
LEV & 0.046 & LEV & 0.04 & LEV & 0.039 \\
& -0.663 & & -0.576 & & -0.569 \\
IND & Control & IND & Control & IND & Control \\
\hline Adj R2 & 0.131 & & 0.131 & & 0.131 \\
F(P) & $19.585(.000)$ & & $19.586(.000)$ & & $19.643(.000)$ \\
VIF & 1.655 & & 1.655 & & 1.655 \\
$\mathrm{~N}$ & 2098 & & 2098 & & 2098 \\
\hline
\end{tabular}

Note: 1) Model: $\triangle \mathrm{MVS}_{\mathrm{it}+1}=\beta_{0}+\beta_{1} \mathrm{EDI}_{\mathrm{it}}+\beta_{2} \operatorname{Size}_{\mathrm{it}}+\beta_{3} \operatorname{Lev}_{\mathrm{it}}$ $\left.+\Sigma \gamma_{\mathrm{j}} \mathrm{IND}_{\mathrm{j}}+\varepsilon ; 2\right)^{* * *}, * *$ and $*$ is $1 \%, 5 \%$ and $10 \%$ significant level.

\section{CONCLUSION}

This paper inspects the ownership concentration of influence environmental information disclosure and market reactions. The research gains the following conclusions: (1) Institutional investors, tradable share proportion have significant positive effect on environmental information disclosure of listed companies. Listed companies with higher tradable shares, and the higher the institutional investor shareholding will be more and better disclosure of environmental information. (2) The listed companies environmental information disclosure behavior index and disclosure quality index are all significantly positive with the company's next seasonal added value. Indicate that environmental information disclosure has significantly increased the value of the company. Capital market response 
strongly to the environmental information disclosure. Environmental information disclosure behavior and disclosure quality played the role of market mechanism, and exerted positive influence on investors' decision-making and company's market value in a certain extent.

This article contribution mainly expression: First, institutional investors and tradable share have significant positive effect on the enterprise environment accounting information disclosure, this enrich the academic achievements of environmental information disclosure influencing factors research. Second, the higher environmental information disclosure and disclosure quality level are, the higher added market value is, which is beneficial to promote enterprise voluntary disclosing environmental information.

\section{ACKNOWLEDGEMENT}

Project funding: Shandong social science planning project (16CKJJ21), phased research results.

\section{REFERENCES}

[1] Anderson, J., and A. Frankle. Voluntary Social Reporting: An IsoBeta portfolio analysis[J].Accounting Review, 1980(55): 467-479.

[2] Ahmad, Z., S. Hassan, \& J. Mohammad. 2003.Determinant of Environmental Reporting in Malaysia . International Journal of Business Studies, Vol. 11, Jan. PP 69-90.

[3] Belkaoui A. The Impact of the Disclosure of the Environmental Effects of Organizational Behavior on the Market[J]. Financial Management, 1976(5) : 26-31

[4] Brammer, S. J. \& S. Pavelin. 2006. Voluntary Environmental Disclosures by Large UK Companies . Journal of Business Finance \& Accounting, Vol. 33, July. PP1168-1188.

[5] Bowman, E. Strategy, Annual Reports and Alchemy[J].California Management Review,1978(20) : 64-71.

[6] Chung, R., M. Firth, \& J. B. Kim. 2002. Institutional Monitoring and Opportunistic Earnings Management. Journal of Corporate Finance, Vol. 8, ,PP 29-48.

[7] Clarkson, P. M., Y. Li, G.D. Richardson, \& F. P. Vasvari. 2008. Revisiting the Relation between Environmental Performance and Environmental Disclosure: An Empirical Analysis Accounting. Organizations and Society, Vol. 33(4/5) PP303-327.

[8] Cormier D., \& I. M. Gordon. 2001. An Examination of Social and Environmental Reporting Strategies. Accounting Auditing \& Accountability Journal, Vol. 14, May, PP587-616.

[9] Dierkes, M., \& R. Coppock. 1978. Europe tries the Corporate Cocial Report. Business and Society Review, Vol.16, PP 21-24.

[10] Eng, L. L., \& Y. T. Mak. 2003. Corporate Governance and Voluntary Disclosure. Journal of Accounting and Policy, Vol. 22, April, PP325 -345 .

[11] Ferguson, L. L. 2002. Voluntary Disclosure by State-Owned Enterprises Listed on the Stock Exchange of Hong Kong. Journal of International Financial Management and Accounting, Vol. 13, pp125151.

[12] Frost, G.R, and T. D. Wilmshurst. Corporate Environmental Reporting: A test of Legitimacy Theory[J].Accounting, Auditing \& Accountability Journal, 2000(13) : 10-26.

[13] Halme, M. \& M. Huse. 1997.The influence of corporate governance, industry and country factors on environmental reporting. Scandinavian Journal of Management, Vol. 13, Feb., PP137-157.

[14] Ingram, R., and K. Frazier. Environmental Performance and Corporate Disclosure[J].Journal of Accounting Research, 1980(18):614-622.
[15] Maug E. 1998. Large shareholders as monitors: is there a trade-off between liquidity and control? The Journal of Finance, Vol. 33, Jan., PP65-98.

[16] Mitra, S. 2002. The impact of institutional stock ownership on a firm's earnings management practice: An empirical investigation. Unpublished Dissertation, Louisiana State University.

[17] Porteiro, Nicolas. 2008. Pressure Groups and Experts in Environmental Regulation. Journal of Economic Behavior \& Organization, Vol. 65, Jan., PP156-175.

[18] Saunders, A., V. Ivashina, V. B. Nair, N. Massoud, and R. Stover. 2006. Bank debt and corporate governance. EFA 2004 Maastricht Meetings Paper, No. 4601.

[19] Shleifer A. \& R. Vishny. 1986. Large shareholders and corporate control. Journal of Political and Economics, Vol. 94, PP 461-88.

[20] Trotman, K., and G. Bradley. Between Social Responsibility Disclosure and Characteristics[J].Accounting, Organizations and Society, 1981(6):355-362. 